\title{
How Does Support by the Organization Decrease Employee's Intention to Leave?
}

\author{
Novianthi Dian Purnamawati, ${ }^{1,2}$, Debora Eflina Purba ${ }^{2}$ \\ ${ }^{1}$ Center for Learning Resources Universitas Indonesia. Gedung ILRC Kampus UI Depok. \\ 16424. Tel. 021-78886707 \\ ${ }^{2}$ Faculty of Psychology Universitas Indonesia. Kampus UI Depok. 16424. Tel. 021-7270004

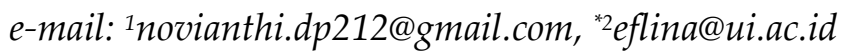

\begin{abstract}
This study aims to investigate the mediating effect of affective commitment in the relationship between perceived organizational support and turnover intention. Data were collected using paper-and-pencil survey on inbound Customer Service Officers (CSO) of a Contact Center $X$ in Jakarta operating in service of electricity needs by phone calls $(N=96)$. Data were analyzed using Hayes PROCESS macro on SPSS software. Results showed that perceived organizational support was negatively related to turnover intention and positively related to affective commitment. Results also showed that affective commitment was negatively correlated with turnover intention. The mediation analysis showed that affective commitment fully mediated the relationship between perceived organizational support and turnover intention. The theoretical and practical implications of the study were further discussed.
\end{abstract}

Keywords: affective commitment, perceived organizational support, and turnover intention.

Abstrak. Penelitian ini bertujuan untuk menguji efek mediasi dari komitmen afektif pada hubungan antara persepsi karyawan pada dukungan organisasi dan intensi meninggalkan organisasi. Penelitian ini menggunakan desain korelasional dengan mengambil data dari sebuah organisasi di Jakarta yang bergerak di bidang jasa $(N=96)$. Organisasi tersebut mengalami masalah terkait dengan cukup banyaknya karyawan meninggalkan organisasi yang berakibat pada rendahnya kepuasan pelanggan pada jasa organisasi tersebut. Data diperoleh menggunakan desain korelasional menggunakan survey kepada karyawan dan dianalisis menggunakan macro PROCESS dari Hayes pada program SPSS. Hasil penelitian menunjukkan bahwa persepsi dukungan organisasi berkorelasi negatif dengan intensi meninggalkan organisasi, dan komitmen afektif berperan sebagai mediator pada hubungan antara persepsi dukungan organisasi dan intensi meninggalkan organisasi.

Kata kunci: intensi meninggalkan organisasi, komitmen afektif, persepsi dukungan organisasi

Employee turnover is harmful to organizational performance (Biron \& Boon, 2012; Glebbeek \& Bax, 2004). Turnover may negatively affect organizations in the form of a decreased number of human capital, work functions, productivity, and increased recruitment and selection costs and loss of knowledge (Biron \& Boon, 2012; Hausknecht \& Trevor, 2011). Turnover is defined as the departure of an individual from an organization (Tett \& Meyer, 1993), or in other words is the breakup of an individual's working relationship with an organization. Park and Shaw (2013) 
distinguished two types of turnover based on the reason for their departure, namely voluntary turnover initiated by the employee itself (employee resignation), and involuntary turnover undertaken by the organization (dismissal or termination of employees).

Turnover intention is the behavioral intention of employees that triggers actual voluntary turnover behavior (Hongvichit, 2015; Mobley, Horner, \& Hollingsworth, 1978). Turnover intention is the last step of a sequence of individual withdrawal thinking, in which individuals think to quit the organization and to search for alternative organizations (Mobley, Horner, \& Hollingsworth, 1978). Based on this understanding, it can be concluded that the turnover intention is more closely related to voluntary turnover. Employees with turnover intentions are said to bring inappropriate behaviors to the organization, some of them are the emergence of poor serving behavior to customers, less organizational citizenship behavior, and degradation of job satisfaction and organizational commitment (Biron \& Boon, 2012).

Given the negative impacts of turnover intention, it is imperative for the organization to identify its antecedents that will enable the organization to fix conditions that cause employee's turnover intention so that the voluntary turnover rate can be better managed (Purba, Oostrom, Born, \& van der Molen, 2016). In the metaanalysis study by Hancock, Allen, Bosco, and Pierce (2011), several factors causing turnover intention are employee demographic factors, job satisfaction, organizational commitment, and job embeddedness. Several other studies have suggested that employee perceptions of organizational support are one of the antecedents of the actual turnover and turnover intention (Allen, Shore, \& Griffith, 2003; Dawley, Houghton, \& Bucklew, 2010; Wayne, Shore, \& Liden, 1997).

We conducted the study in a Contact Center company located in Jakarta. Contact Center is a central point company to manage various types of communication with customers. It is a technological evolution of Call Center that not only serves phone calls but also email and web inquiry services, VoIP, facsimile, web chats, and printed letters. Contact Center management should be designed in such a way to be able to achieve a competitive advantage that focuses on three main business objectives: revenue generation, efficiency, and customer satisfaction (Contact Center Overview, 2008). According to Reynolds (2015), turnover is currently the main problem faced by this type of service. In a Contact Center X Jakarta site which operating in service of electricity needs, the company records showed that the voluntary turnover rates of inbound CSOs have increased from $7 \%$ in 2015 to $13 \%$ in 2016. This problem has had some negative impacts on organization performance and customer satisfaction. Recent policy on zero recruitment worsens the problem in the company. Considering these negative impacts of turnover intention as Biron and Boon (2012) stated, we conducted the study to find the antecedents of turnover intention in inbound CSOs, to avoid the future voluntary turnover. 
Based on an interview with the management of Contact Center $X$ Jakarta (personal communication, January 23, 2017), factors that influence turnover intention of inbound CSOs include employees' perception that the organization has given less concern and support towards their contribution, such as the incompatibility of rewards and benefits, unfairness in job promotion, decrease in development program, and less recognition from their supervisor. These symptoms indicated that there were lower levels of perceived organizational support that may cause higher turnover intentions. Based on the diagnosis, this research study will focus on perceived organizational support as a predictor of turnover intention in inbound CSOs Contact Center X Jakarta.

Previous research found that perceived organizational support predicted turnover intention (Dawley et al., 2010; Kurtessis, Eisenberger, Ford, Buffardi, Stewert, \& Adis, 2015; Rhoades \& Eisenberger, 2002; Riggle, Edmondson, \& Hansen, 2009; Tuzun \& Kalemci; Kahumuza \& Schlechter, 2008). The correlation between perceived organizational support and turnover intentions is known to be negative (Allen et al., 2003; Dawley et al., 2010; Wayne, Shore, \& Liden, 1997). The perceived organizational support itself is defined as employee beliefs about the organization, that they think the organization values their contribution and cares about their wellbeing (Eisenberger, Huntington, Hutchison, and Sowa, 1986). Organizational supports can be in the form of fairness in treatment among employees, supports by the supervisor, fair rewards, and good work environment (Rhoades \& Eisenberger, 2002). Procedural justice concerns the fairness of procedures used by the organization to develop the resource distribution among employees. A variety of rewards and work environment related to perceived organizational support includes employee recognition, compensation and benefits, promotion, autonomy, and personal development (Rhoades \& Eisenberger, 2002). Fairness, supervisor support, and supporting environment should increase employees' desire to stay in the organization and reduce the occurrence of withdrawal behavior such as intention to quit from an organization. Based on the above argument, we formulated the first hypothesis:

$$
\begin{aligned}
& \text { Hypothesis 1: There is a negative } \\
& \text { relationship between perceived } \\
& \text { organizational support and turnover } \\
& \text { intention. }
\end{aligned}
$$

However, previous research found that the relationship between perceived organizational support and withdrawal behaviors (turnover intention, turnover, and other) were inconsistent. In metaanalysis research by Rhoades and Eisenberger (2002), it was found that the relationship between the two was negative with the range of small to medium correlation coefficients $(r=.11$ to $.45, p<$ .001), but the meta-analysis research conducted by Riggle et al. (2009) found a strong negative correlation between perceived organizational support and turnover intention. Another study 
conducted by Fazio, Gong, Sims, \& Yurova (2017) found that affective commitment moderated the relationship between perceived organizational support and turnover intention. The inconsistent results of the findings suggested the need to reevaluate the relationship between perceived organizational support and turnover intention.

We argue that affective commitment mediates the perceived organizational support and turnover relationship. Affective commitment is defined as "an employee's emotional attachment to, identification with, and involvement in the organization" (Meyer \& Allen, 1991, p. 67). Previous research found that perceived organizational support positively correlated with affective commitment (Rhoades, Eisenberger, \& Armeli, 2001; Rhoades \& Eisenberger, 2002). Fair treatment from the organization, supervisor support for their well-being, and supporting job conditions can meet employee needs related to selfesteem, acceptance, and affiliation that may lead to employees' desire to identify themselves with the organization. Selfidentification with the organization is an indication of high affective commitment (Meyer \& Allen, 1991).

Another previous research found that affective commitment was an important factor of turnover intention (Meyer \& Allen, 1997). A finding from Tett \& Meyer (1993) showed that affective commitment had a negative relationship with the turnover intention and actual turnover. Individuals with high-affective commitment would have a high emotional attachment to their organization and want to identify themselves as part of the organization. In other words, they would stay in their organizations because they want it and would reduce their intention to quit from the organization (Meyer \& Allen, 1991; Kahumuza \& Schletcher, 2008; Wong \& Wong, 2017). Based on the argumentation, we hypothesize the following:

Hypothesis 2: There is a positive
relationship between perceived
organizational support and affective
commitment.
Hypothesis 3: There is a negative
relationship between affective
commitment and turnover intention.

As we have mentioned above, previous studies found inconsistent magnitude of correlation results on the relationship between perceived organizational support and turnover intention (see meta-analysis works by Rhoades \& Eisenberger, 2002 and Riggle et al., 2009). Furthermore, some studies from other countries found that affective commitment was one of the mediator variables between perceived organizational support and turnover intention (Kahumuza \& Schlechter, 2008; Wong \& Wong, 2017), indicating that employees' perception that their organization values his/her contributions and pays attention to their well-being, would lead to their desire to identify themselves with the organization (Rhoades, Eisenberger, \& Armeli, 2001). This opinion is consistent with Meyer and Allen (1991) who argued that affective commitment was the employee's emotional 
attachment to, identification with, and involvement in the organization. Research from Indonesia showed that employee's identification with the organization was a reflection of employee's identification with their manager/supervisor (Purba, Oostrom, Van der Molen \& Born, 2015). Managers are expected to create a so-called 'surrogate' family for their employees, in which employees regard their managers as a 'father' who are supposed to look after his/her employees. This type of managersubordinate relationship is bound by covenantal relationship, a type of relationship in which two parties agree to support and involve themselves holistically for each other's welfare (Purba et al., 2015). A breach of the covenantal relationship may decrease employee affective commitment.

Furthermore, high levels of affective commitment will lead to low turnover intention because they identify with the organization and thus want to stay in the organization (Meyer \& Allen, 1991). This argumentation indicates the proximal relationship between affective commitment and turnover intention compared to the relationship between perceived organizational support and turnover intention. Therefore, based on the previous studies, we replicated the model to our current organization and hypothesized the following:

Hypothesis 4: affective commitment mediated the relationship between perceived organizational support and turnover intention.

\section{Method}

\section{Participant}

The research was conducted at a Contact Center $X$ Jakarta site managed by BCD Company, with the population number 230 employees. Participants involved are inbound Customer Service Officer (CSO) that are tasked to serve customer needs related to the service of electric power requirements (handling general information such as products and services, requests, and customer complaints) by phone and have been working for at least three months. We employed convenience sampling in which we only got data based on the availability of inbound CSOs at the time of data collection. We sent out 150 questionnaires and managed to collect 96 questionnaires (response rate $=64 \%$ ). In the cover letter we explained that their participation was voluntary, in which they were allowed to quit their participation whenever they wanted. We also assured them that their participation was confidential and anonymous.

The study participants consisted of 50 male participants $(52.1 \%)$ and 46 female participants (47.9\%). Most participants were in the age range of $20-30$ years $(80.2 \%)$. In the educational background data, most of the participants have an undergraduate education $(45.78 \%)$, others are diploma graduates $(41.7 \%)$, high school $(11.5 \%)$, and other education (1.0\%). For working period data, most of the participants had worked for over three years $(78.1 \%)$. 


\section{Measures}

All measuring instruments used were the results of adaptation of available measures that was translated from English to Indonesia using translate-back translation method suggested by Brislin (1970).

Turnover intention was measured using a 5-item scale from Bozeman and Perrewe (2001) which referred to Mobley et al. (1978). An item example was "At present, I am actively searching for another job in the different organization" and "I do not intend to quit my job" ( $\alpha=0.85)$.

Perceived organizational support was measured using 14 items which were a shortened version of a total of 32 items developed by Eisenberger et al (1986). Examples of the items were "The organization fails to appreciate any extra effort from $m e "$ and "Help is available from the organization when I have a problem" $(\alpha=0.93)$.

Affective commitment was measured using five items adapted from Meyer, Allen, and Smith (1993). Examples of the items were "I would be very happy to spend the rest of my career with this organization" and "I do not feel emotionally attached to this organization" $(\alpha=0.90)$. The overall measuring tool used Likert scale 1-6 ( 1 = strongly disagree, 6 = Strongly agree).

\section{Procedures}

Before conducting the survey, we first asked the company for permission to conduct the survey to their employees. Afterwards, we approached employees to participate in the survey, by ensuring that their participation is voluntary and anonymous, and that their data would be kept confidential. Each participant took 1520 minutes to complete all the questionnaires.

\section{Data Analysis}

This study used statistical analyses of SPSS (Statistical Package for the Social Science) version 2.3. The statistical analysis techniques included Macro PROCESS on SPSS from Hayes, used to test the mediation effect of affective commitment on the relationship between perceived organizational support and turnover intentions. According to Preacher and Hayes (2008), the macro for SPSS is powerful to estimate the path coefficients and generate bootstrap confidence intervals for total and specific indirect effects of $X$ on $Y$. The PROCESS macro has an advantage because its existing bootstrapping techniques could estimate standard errors with $95 \%$ and $99 \%$ confidence intervals in a population and could do sampling with replacement of a large number of samples and calculate the indirect effects between variables (Preacher \& Hayes, 2004).

\section{Results}

Table 1 showed participants' characteristics based on gender, age, education, and length of employment in the company. The results of the correlation analyses (Table 2) showed the descriptive analyses of our study variables. Hypothesis 1 stated that there was a negative relation between perceived organizational support and turnover intention. Table 2 showed that perceived organizational support negatively correlated with the turnover intention $(r=$ 


\begin{tabular}{|c|c|c|}
\hline $\begin{array}{l}\text { Table 1. Particip } \\
\text { Characteristics (l }\end{array}$ & Dem & \\
\hline Characteristic & $N$ & $\%$ \\
\hline
\end{tabular}

\section{Gender}

$\begin{array}{lll}\text { Female } & 46 & 47.9 \% \\ \text { Male } & 50 & 52.1 \%\end{array}$

\section{Age}

$\begin{array}{lll}20-30 \text { years } & 77 & 80.2 \% \\ 31-40 \text { years } & 19 & 19.8 \%\end{array}$

\section{Education}

$\begin{array}{lcc}\begin{array}{l}\text { High school } \\ \text { diploma }\end{array} & 11 & 11.5 \% \\ \begin{array}{l}\text { College diploma } \\ \text { Undergraduate }\end{array} & 40 & 41.7 \% \\ \text { diploma } & 44 & 45.78 \% \\ \begin{array}{l}\text { Graduate } \\ \text { diploma }\end{array} & 1 & 1.0 \%\end{array}$

\section{Length of employment}

\begin{tabular}{lcc} 
Under 1 year & 5 & $5.2 \%$ \\
$1-3$ years & 16 & $16.7 \%$ \\
More than 3 years & 75 & $78.1 \%$ \\
\hline
\end{tabular}

$0.426, p<.001)$. Thus, our data support Hypothesis 1. In other words, individuals with higher levels of perceived organizational support tend to have lower turnover intention.

Hypothesis 2 stated that there was a positive relationship between perceived organizational support and affective commitment. Results showed that perceived organizational support positively correlated with affective commitment $(r=$ $.638, p<.001)$. Therefore, our data support our Hypothesis 2, wherein individuals with higher perceived organizational support tend to have high levels of affective commitment.

Hypothesis 3 stated that there was a negative relationship between affective commitment and turnover intention. Results showed that affective commitment negatively correlated with the turnover intention $(r=.624, p<.001)$. Thus, our data support our Hypothesis 3, in which individuals with higher level of affective commitment tend to have lower intentions of turnover. When the relationship between these three variables was significant, the researchers conducted further analysis to test the research hypothesis.

Table 2. Means, Standard Deviations, and Correlations Between Study Variables

\begin{tabular}{lccccccc}
\hline & Mean & SD & $\mathbf{1}$ & $\mathbf{2}$ & $\mathbf{3}$ & $\mathbf{4}$ & $\mathbf{5}$ \\
\hline 1. POS & 3.47 & .815 & .93 & & & & \\
2. Affective commitment & 3.37 & 3.37 & $.638^{* *}$ & $\mathbf{. 9 0}$ & & & \\
3. Turnover intention & 3.84 & 1.15 & $-.426^{* *}$ & $-.624^{* *}$ & .85 & & \\
4. Education & 2.36 & .697 & -.078 & -.088 & $.212^{*}$ & NA & \\
5. Tenure & 3.67 & .732 & -.033 & -.151 & .153 & .068 & NA \\
\hline
\end{tabular}

$\mathrm{N}=96$. Cronbach's Alphas of each measuring instrument are presented on the diagonal, ${ }^{* *} \mathrm{p}<.01,{ }^{*} \mathrm{p}<.05$. NA $=$ not applicable. POS $=$ perceived organizational support. Tenure was measured in years. Education was dummy-coded ( 1 = high school, 2 = diploma, 3 = bachelor, 4 = others). 
Table 3. Affective Commitment as a Mediator in the Relationship between Perceived Organizational Support and Turnover Intention

\begin{tabular}{|c|c|c|c|c|c|c|c|c|}
\hline \multirow[b]{3}{*}{ Antecedents } & \multicolumn{8}{|c|}{ Outcomes } \\
\hline & \multicolumn{5}{|c|}{ M (Affective Commitment) } & \multicolumn{3}{|c|}{ Y ( Turnover Intention) } \\
\hline & & Coefficient & SE & $p$ & & Coefficient & $S E$ & $p$ \\
\hline $\mathrm{X}(P O S)$ & $a$ & .2523 & .0317 & .000 & $\begin{array}{l}c \\
c^{\prime}\end{array}$ & $\begin{array}{l}-.2070 \\
-.0233\end{array}$ & $\begin{array}{l}.0466 \\
.0529\end{array}$ & $\begin{array}{l}.000 \\
.6604\end{array}$ \\
\hline $\begin{array}{l}\text { M (Affective } \\
\text { Commitment) }\end{array}$ & & - & - & - & $b$ & -.7280 & .1339 & .000 \\
\hline \multirow[t]{2}{*}{ Constant } & & 7.9921 & $\begin{array}{l}2.7302 \\
\mathrm{R}^{2}=.65\end{array}$ & .0043 & & 28.0201 & $\begin{array}{l}3.6670 \\
\mathrm{R}^{2}=.64\end{array}$ & .000 \\
\hline & \multicolumn{5}{|c|}{$\mathrm{F}(3,92)=22.6957 ; p<0,01$} & \multicolumn{3}{|c|}{$F(4,91)=16.3715 ; p<0.01$} \\
\hline
\end{tabular}

Note. Indirect effect $=-.1837$, Boot $S E=.0455,95 \% C I=[-.2834,-.1037]$. POS $=$ perceived organizational support. $a=$ path coefficient between POS and affective commitment. $b=$ path coefficient between affective commitment and turnover intention. $c=$ total effect of POS on turnover intention before affective commitment was included in the model. $c^{\prime}=$ direct effect of POS on affective commitment after affective commitment was included in the model.

Hypothesis 4 stated that affective commitment mediated the relationship between perceived organizational support and turnover intention. The analysis of the mediation test was performed using Hayes's PROCESS macro on SPSS software. Our confidence interval was based on the bias-corrected method with 5.000 bootstrap samples. The results in Table 3 showed that the indirect effect of perceived organizational support on the turnover intention through affective commitment was significant (indirect effect $=-.1837, S E=$ $.0455,95 \%$ CI [-.2834, -.1037]). Therefore, it can be concluded that affective commitment mediated the relationship between perceived organizational support and turnover intention. Thus, our Hypothesis 4 was supported by our data. The direct effect of perceived organizational support on the turnover intention became nonsignificant (direct effect $=-.0233$, SE $=.0529,95 \%$ CI [$.1284,0818]$ ) after affective commitment went into the model as a mediator. Therefore, we can conclude that affective commitment fully mediated the relationship between perceived organizational support and turnover intention.

\section{Discussion}

The main objective of this research was to examine the mediation effect of affective commitment on perceived organizational support and turnover intention. Based on the overall results of this study, it can be concluded that affective commitment fully mediated the relationship between perceived organizational support and turnover intention. Specifically, it can be explained that employees who assume that their organization supports and consider 
their well-being will feel attached and identify themselves in the organization as an indication of high affective commitment and thus have lower intention to leave the organization.

All the results supported all hypothesis in accordance with the results of previous research which stated that perceived organizational support had a negative relationship to turnover intentions (Allen et al., 2003; Dawley et al., 2010; Wayne et al., 1997), perceived organizational support had a positive relationship with affective commitment (Rhoades et al., 2001), and affective commitment had a negative relationship with turnover intentions (Meyer \& Allen, 1997).

Also, our results showed that one of the demographic data, namely education variable, positively correlated with turnover intention $(r=.212, p<.05)$. The result was consistent with previous metaanalysis research which claimed that bettereducated workers often have more employment options available to them, and thus may be more likely to think of leaving their jobs (Alsaraireh, Griffin, Ziehm, \& Fitzpatrick, 2014; Barak, Levin, Nissly, \& Lane, 2006).

Other results showed that the direct effect of perceived organizational support on the turnover intention after controlling for affective commitment became nonsignificant, indicating a full mediation of affective commitment. The result was in line with previous research which claimed that affective commitment was the mediator variable between perceived organizational support and turnover intention (Kahumuza
\& Schlechter, 2008; Wong \& Wong, 2017). As mentioned in the previous section, there were two different meta-analytical results on the relationship between perceived organizational support and turnover intention. On the one hand, Rhoades and Eisenberger (2002) found moderate negative correlations between perceived organizational support and turnover intention, indicating an indirect relationship between the variables. On the other hand, Riggle et al. (2009) found strong negative correlations between perceived organizational support and turnover, indicating a direct relationship to occur between them. Fazio et al. (2017) found the moderating effect of affective commitment in the relationship between perceived organizational support and turnover intention. The inconsistent findings provided a rational for our study. Based on our findings, we contribute to the literature by confirming that concern and support from organizations as perceived by employees are essential for individuals to develop their sense of belongingness to be part of the organization regardless of countries and cultures.

For practical implications, there are several human resource practices to increase employees' perception of fairness, supervisors support, rewards and job conditions, namely performance appraisal system, reward for shift system, and performance feedback by supervisors (Allen et al., 2003). Rhoades and Eisenberger (2002) stated that procedural justice concerns the fairness of the methods used to determine the distribution of resource among employees which have a 
substantial effect on perceived organizational support. Based on this, organizations could design an appropriate performance appraisal system for employees, such as using 360-degree feedback method. According to Robbins and Judge (2015), performance appraisal can help management to make general human resource decisions about promotions, rotations, terminations. Performance appraisal also can help managers to identify training and development needs and serve as a basis to allocate reward and merit pay increase (Robbins \& Judge, 2015). By using the 360degree feedback system, the organization would give more comprehensive, objective, and accurate appraisal result for employees (Cummings \& Worley, 2009), that will lead to high perceived of fairness because the employee will receive adequate notice and information before decision and distribution are implemented.

Another practical implication for organizations is to provide adequate rewards and job conditions (Cummings \& Worley, 2009; Willis, O'Connor, \& Smith, 2008). Since inbound CSOs work on a shift system, reward and job conditions must be adjusted with their shift load to provide safe and healthy work environments (Willis et al., 2008). These include making a distinction of benefit allocations for inbound CSOs because of different shift time. In other words, inbound CSOs who work early in the morning and in the evening should get different amount and type of benefits because of the risk factors. The second way is to provide inbound CSOs with some of the refreshment activities periodically, such as family gathering and sports tournament, which could help them to release the stress for a while (Voydanoff, 1988). Third, the organization should arrange an appropriate job design for inbound CSOs career path, training and development needs, and reward. Currently, the career path in the organization which we conducted the study is limited for CSOs. Lastly, the organization should increase the supervisor's capability to give supports to employees. The supervisor is an organizational agent that provide direction to their subordinates (Rhoades \& Eisenberger, 2002). All forms of treatment provided by supervisor contribute significantly to the increase in perceived organizational support (Rhoades \& Eisenberger, 2002) and affective commitment (Purba et al., 2015). One example is by giving effective performance feedback for employees as a form of support and concern from the supervisor (Aguinis, Gottfredson, \& Joo, 2012).

We should note several limitations of this research. Firstly, this research was only conducted in one Contact Center, implying that the research result might not be generalized to the population of all Contact Center industry outside Jakarta because of the difference in policies. Secondly, self-report survey and the presence of the Head of the Contact Center at survey time may cause biases such as common method variance and social desirability issues. Thirdly, the crosssectional design of the study limits our ability to confirm the causal relationship between variables. Thus, we suggest several directions to address the problem for future 
research. First, subsequent research should get more contact center participants so that the results could be generalized to the entire population of inbound CSOs of contact centers. Second, future research should provide convenience on the part of participants to avoid bias by eliminating the attendance of Head or other supervisors when taking the data to assure the confidentiality of the research. Third, further research can perhaps use a longitudinal research design in which data are collected intermittently over time from the same group of people to confirm the causal relationships between study variables.

\section{Conclusion}

Our study was aimed at investigating the mediating effect of affective commitment in the relationship between perceived organizational support and turnover intention. Our findings confirmed the previous research by showing that affective commitment is a significant mediator in the relationship between perceived organizational support and turnover intention. Our study contributes to the literature by confirming the role of affective commitment as a mediator instead of moderator in the relationship between perceived organizational support and turnover intention.

\section{References}

Aguinis, H., Gottfredson, R. K., \& Joo, H. (2012). Delivering effective performance feedback: The strengthsbased approach. Business Horizons, 55,
105-111.

doi:

10.1016/j.bushor.2011.10.004

Allen, D.G., Shore, L.M., \& Griffeth, R.W. (2003). The role of perceived organizational support and supportive human resource practices in the turnover process. Journal of Management, 29, 99-118. doi:10.1016/S0149-2063(02)00222-2

Alsaraireh, F., Quinn Griffin, M. T., Ziehm, S. R., \& Fitzpatrick, J. J. (2014). Job satisfaction and turnover intention among Jordanian nurses in psychiatric units. International Journal of Mental Health Nursing, 23, 460-467. doi: 10.1111/inm.12070

Barak, M. E. M., Levin, A., Nissly, J. A., \& Lane, C. J. (2006). Why do they leave? Modeling child welfare workers' turnover intentions. Children and Youth Services Review, 28, 548-577. doi: 10.1016/j.childyouth.2005.06.003

Biron, M., \& Boon, C. (2012). Performance and turnover intentions: a social exchange perspective. Journal of Managerial Psychology, 28, 511-531. doi: 10.1108/JMP-09-2011-0054.

Brislin, R.W. (1970). Back-translation for cross-cultural research. Cross-Cultural Psychology, 01, 185-216.

Bozeman, D.P., \& Perrewe, P.L. (2001). The effect of item content overlap on organizational commitment questionnaire - turnover cognitive relationships. Journal of Applied Psychology, 86, 161-173. doi: 10.1037//0021-9010.86.1.161.

Contact Center Overview. (2008). Retrieved from The Global CC Community website: GloCCall.com 
Cummings, T.G., \& Worley, C.G. (2009). Organizational Development and Change $9^{\text {th }} \quad E d$. Canada: South-Western Cengage Learning.

Dawley, D., Houghton, J.D., \& Bucklew, N.S. (2010). Perceived organizational support and turnover intention: the mediating effects of personal sacrifice and job fit. The Journal of Social Psychology, 238-257. doi: 10.1080/00224540903365463.

Eisenberger, R., Huntington, R., Hutchison, S., \& Sowa, D. (1986). Perceived organizational support. Journal of Applied Psychology, 71, 500-507. doi: 10.1037/0021-9010.71.3.500.

Fazio, J., Gong, B., Sims, R., \& Yurova, Y. (2017). The role of affective commitment in the relationship between social support and turnover intention. Management Decision, 55, 512-525.

Hancock, J.I., Allen, D.G., Bosco, F.A., McDaniel, K.R., \& Pierce, C.A. (2011). Meta-analytic review of employee turnover as a predictor of firm performance. Journal of Management, 131. doi: 10.1177/0149206311424943.

Hausknecht, J. P., \& Trevor, C. O. (2011). Collective turnover at the group, unit, and organizational levels: Evidence, issues, and implications. Journal of Management, 37, 352-388. doi: $10.1177 / 0149206310383910$

Head \& Coordinator of Operational Contact Center X Jakarta. (2017, January 23-24). Personal interview.

Hongvichit, S. (2015). The research progress and prospect of employee turnover intention. International Business Research, 218-223. doi: 10.5539/ibr.v8n6p218.

Kahumuza, J., \& Schlechter, A.F. (2008). Examining the direct and some mediated relationships between perceived support and intention to quit. Management Dynamics: Journal of the Southern African Institute for Management Scientist, 17, 2-19.

Kurtessis, J.N., Eisenberger, R., Ford, M.T., Buffardi, L.C., Stewart, K.A., \& Adis, C.S (2015). Perceived organizational support: A meta-analytic evaluation of organizational support theory. Journal of Management. doi: 10.1177/0149206315575554. Retrieved from jom.sagepub.com.

Meyer, J.P., Allen, N. (1991). A threecomponent model conceptualization of organizational commitment. Human Resource Management Review, 1, 61-89. doi: 10.1016/1053-4822(91)90011-Z.

Meyer, J.P., Allen, N.J., \& Smith, C.A. (1993). Commitment to the organizations and occupations: extensions and test of a threecomponent conceptualization. Journal of Applied Psychology, 78, 538-551. doi: 10.1037/0021-9010.78.4.538

Meyer, J.P., Allen, N.J. (1997). Commitment in the Workplace: Theory, Research, and Application. Thousand Oaks: Sage Publications.

Mobley, W.H., Horner, S.O., \& Hollingsworth, A.T. (1978). An evaluation precursor of hospital employee turnover. Journal of Applied Psychology, 63, 408-414. doi: 10.1037/0021-9010.63.4.40 
Park, T.Y., \& Shaw, J.D. (2013). Turnover rates and organizational performance: a meta-analysis. Journal of Applied Psychology, 98, 268-309. doi: 10.1037/a0030723.

Preacher, K.J., \& Hayes, A.F. (2008). Asymptotic and resampling strategies for assessing and comparing indirect effects in multiple mediator models. Behavior Research Methods, 40, 879-891. Retrieved from http://afhayes.com/spss-sas-and-mplusmacros-and-code.html.

Purba, D. E., Oostrom, J. K., van der Molen, H. T., \& Born, M. P. (2015). Personality and organizational citizenship behavior in Indonesia: The mediating effect of affective commitment. Asian Bussiness $\mathcal{E}$ Management, 1-24. doi: 10.1057/abm.2014.20.

Purba, D. E., Oostrom, J. K., Born, M. P., \& van der Molen, H. T. (2016). The relationships between trust in supervisor, turnover intentions, and voluntary turnover: Testing the mediating effect of on-the-job embeddedness. Journal of Personnel Psychology, 174-183. doi: 10.1027/18665888/a000165.

Rhoades, L., Eisenberger, R., \& Armeli, S. (2001). Affective commitment to the organization: the contribution of perceived organizational support. Journal of Applied Psychology, 86, 825836. doi: 10.1037//0021-9010.86.5.825.

Rhoades, L., \& Eisenberger, R. (2002). Perceived organizational support: A review of the literature. Journal of Applied Psychology, 87, 698-714. doi: 10.1037//0021-9010.87.4.698.
Riggle, R. J., Edmondson, D. R., \& Hansen, J. D. (2009). A metaanalysis of the relationship between perceived organizational support and job outcomes: 20 years of research. Journal of Business Research, 62, 1027-1030. doi: 10.1016/j.jbusres.2008.05.003

Robbins, S. P., \& Timothy A Judge. (2013). Organizational Behaviour (15th Edition). Boston: Prentice Hall.

Tett, R.P., \& Meyer, J.P. (1993). Job satisfaction, organizational commitment, turnover intention, and turnover: path analysis based on metaanalytic findings. Personnel Psychology, 46, 259-293. doi: 10.1111/j.17446570.1993.tb00874.x

Tuzun, I.K., \& Kalemci, R.A. (2011).

Organizational and supervisory support in relation to employee turnover intentions. Journal of Managerial Psychology, 27, 518-534. doi: $10.1108 / 02683941211235418$.

Voydanoff, P. (1988). Work role characteristics, family structure demands, and work/family conflict. Journal of Marriage and the Family, 749761. doi: $10.2307 / 352644$

Wayne, S.J., Shore, L.M, \& Liden, R.C. (1997). Perceived organizational support and leader-member exchange: a social exchange perspective. The Academy Management Journal, 40, 82111. doi: 10.2307/257021.

Willis, T. A., O'Connor, D. B., \& Smith, L. (2008). Investigating effort-reward imbalance and work-family conflict in relation to morningness-eveningness 
and shift work. Work \& Stress, 22, 125137. doi: $10.1080 / 02678370802180558$

Wong, Y.W., \& Wong, Y.T (2017). The effect of perceived organizational support and affective commitment on turnover intention: a test of two competing models. Journals of Chinese Human Resource Management, 08, 2-21. doi: http://dx.doi.org/10.1108/JCHRM-012017-0001. 